\title{
The Application of Montessori Method in Learning Mathematics: An Experimental Research
}

\author{
Qais Faryadi \\ Future Expert Solutions, Kuala Lumpur, Malaysia \\ Email: qais@magnesium4you.com
}

How to cite this paper: Faryadi, Q. (2017) The Application of Montessori Method in Learning Mathematics: An Experimental Research. Open Access Library Journal, 4: e4140.

https://doi.org/10.4236/oalib.1104140

Received: November 10, 2017

Accepted: November 27, 2017

Published: November 30, 2017

Copyright $\odot 2017$ by author and Open Access Library Inc.

This work is licensed under the Creative Commons Attribution International License (CC BY 4.0).

http://creativecommons.org/licenses/by/4.0/

\section{(c) (i) Open Access}

\begin{abstract}
The prime objective of this research was to investigate whether the Montessori method of learning helped kindergarten pupils improve their mathematical proficiency, critical thinking and problem-solving skills, besides training them to be responsible learners. Quantitative, qualitative, and observational methods were employed in the investigation. The sample for the study comprised 180 kindergarten pupils from TadikaBestari Al-Hidayah, located in Bandar Seri Damansara, Malaysia. The instruments for collecting data were questionnaires, interviews, and field observations. Results from a pre-test and a post-test showed that pupils who used the Montessori method, i.e. the experimental group, outperformed (72.2\% passed) their peers who were not exposed to the Montessori method (39\% passed). The findings indicated that the Montessori method indeed helped learners to improve their mathematical proficiency. This research offers guidelines to future researchers on alternative learning methods, especially for very young children. The findings of this empirical research could be prototyped for learning other subjects.
\end{abstract}

\section{Subject Areas}

Education

\section{Keywords}

Montessori, Learning, Teaching, Sensory, Critical Thinking, Mathematics

\section{Introduction}

The Montessori Method of learning was developed by Dr. Maria Montessori from Italy (trilliummontessori.org, 2017). A medical doctor, she developed a 
very keen interest to help mentally ill and retarded children learn. Montessori strongly believed that learners could teach themselves. Thus, she developed the Montessori method of learning, regarded by scholars and educationists as unique, effective, and efficient. According to study, intervention by adults in times of need effectively helps learners to learn and progress noticeably [1]. Dr. Maria Montessori believed that each learner is a unique being, and he/she can surprise us with unique talents [2]. The theory of Montessori learning is simple. Students learn by playing. Playing is not in the literal meaning, but pretended playing. Today in this age of technology, many researchers believe that students should learn constructively and enjoyably. This type of learning is indeed flexible, active, constructive and fun. The Theory of Montessori learning is based on guided learning using relevant toys that matches children's age and capabilities. In the meantime, an adult takes charge of the student and is ready to help if needs arise. Montessori learning method is based on group learning. Similar age groups are stationed to learn effectively. Montessori students consist of 3 to 12 years of age. The beauty of this methodology is that, materials are kept on the shelves and freely available to the children. During the learning sessions, if a student makes a mistake or has any problem, he/she can refer to the material as a reference point.

\section{Problem Statement}

This research argues that the Montessori method of teaching helps students to learn mathematics faster and improve their critical thinking and problem-solving skills, as well as be responsible learners in the class.

\section{Research Objectives}

This research was aimed at achieving the following objectives:

1) To investigate whether learners improved their problem-solving skills and critical thinking skills when they utilized the Montessori method of learning.

2) To investigate whether using the Montessori method of learning helped learners to improve their mathematical proficiency.

3) To investigate whether learners become more disciplined and responsible by using the Montessori method.

\section{Research Questions}

This research sought to answer the following questions:

1) Do learners improve their problem-solving skills and critical thinking skills when they utilize the Montessori method?

2) Does the Montessori method help raise the level of mathematical proficiency among the pupils?

3) Does the Montessori method assist learners to be more responsible pupils in the class? 


\section{Research Hypotheses}

$\mathrm{H}^{1}$ : Learners who utilize the Montessori method improve their problem-solving skills and critical thinking skills.

$\mathrm{H}^{2}$ : Learners who utilize the Montessori method improve their mathematical proficiency.

$\mathrm{H}^{3}$ : The Montessori method of teaching assists learners to be responsible pupils in the classroom.

\section{Justification of the Research}

1) The findings of this research would contribute to the development of a paradigm of learning, namely the Montessori method of learning. The findings of this empirical research could be prototyped for learning other subjects.

2) This study offers guidelines for the use of a more viable alternative to the traditional methods of teaching mathematics in the Malaysian classroom.

3) Interviews, observations, questionnaires and field worksheets from this study would provide valuable information for other researchers who wish to teach mathematics using the Montessori method.

\section{Literature Review}

To fully develop the unseen potential of our learners, teachers must give them freedom of choice to explore their environment. Instructors should develop the concept of self-respect for their learners as well as train them to respect others [3]. The Montessori Method of teaching concentrates on quality rather than quantity. Teachers assist learners with the sensory-based teaching methodology advocated by Maria Montessori [4]. In addition, it is important that pupils must enjoy the process of learning. In other words, Montessori teachers adopt a holistic approach to enable their pupils to learn more effectively. Every learner is considered as an individual who must not be guided and controlled all the time by an adult [5] [6]. "Scientific observation has established that education is not what the teacher gives, education is a natural process spontaneously carried out by the human individual, and is acquired not by listening to words but by experiences upon the environment. The task of the teacher becomes that of preparing a series of motives of cultural activity, spread over a specially prepared environment, and then refraining from obtrusive interference. Human teachers can only help the great work that is being done, as servants help the master. Doing so, they will be witnesses to the unfolding of the human soul and to the rising of a New Man who will not be a victim of events, but will have the clarity of vision to direct and shape the future of human society". Maria Montessori, Education for a New World: Retrieved from: http://www.michaelolaf.net/maria.html, 2017. In Montessori learning, there is a sense of direction rather than forcing learners to learn [7]. Effective learning happens when the learner's senses are activated. Studies have found that $75 \%$ of learning occurs visually, while $13 \%$ occurs through hearing and touching. Smell and taste account for $12 \%$. So, if multi-senses are 
stimulated, more learning should take place. See Figure 1, it shows students are learning together for collective achievement.

\section{Sensory Method}

The sensory learning programme is an innovative approach that unites three modalities (visual, auditory and vestibular) into one intervention, thus allowing individuals to merge sensory messages for perfect learning outcomes [8] [9]. According to researchers [10], we all learn differently using our dynamic characteristics. We have certain values attached to our learning styles. If we combined all these attached values in cognitive and sensory learning styles, the learning process would be facilitated [11]. Figure 2 below shows how sensory learning method stimulates learner's motivation.

\subsection{Learning and the Mind}

According to Shelly, our mind is like a locked playground. We have to unlock that playground to achieve learning outcomes. So, by applying of all our senses, it is possible to acquire the necessary skills to achieve academic excellence (Shelly, 2002). Research confirms that sensory motor integration helps learners to achieve success and acquire necessary skills. "The Montessori method can be recast as a viable contemporary, constructivist program for early childhood education. Montessori believed that learners in the crucial years from birth to age six possess extraordinary, innate mental powers to absorb the environment' [12]. The Montessori approach is a unique methodology of teaching. It must be applied precisely for a positive outcome. A study by [13] found that Montessori

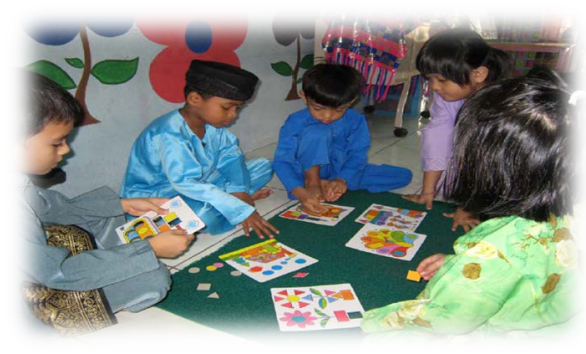

Figure 1. Learning together.

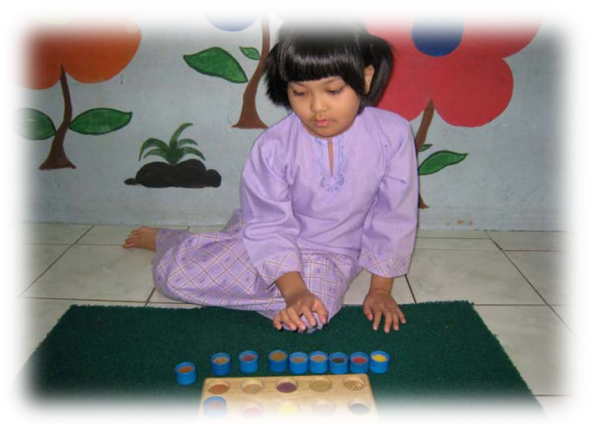

Figure 2. Sensory learning. 
learners performed better compared to those studying in public and private schools which did not adopt the Montessori approach in the classroom. See below Figure 3. Students learn by thinking critically for a perfect outcome.

\subsection{The Instructor's Role}

In the Montessori approach to learning, there is a link between instructors and parents [14]. To learn effectively, Maria Montessori insisted that learners, teachers and parents must co-operate with one another so that young children can learn more effectively. In cooperative learning environment size does not matter, even a single student learns cooperatively. As thus the important of cooperative learning is evident even with one student [15]. Although Piaget and Vygotsky had much respect for Dr. Montessori, they were not happy with her emphasis on a sensorial approach to education. Nevertheless, they utilized the Montessori method as a bridge for constructive accomplishment [16]. In the Montessori class, learners work hands-on and they actually experience the satisfaction of accomplishing a given task. In other words, according to Montessori, the hands play an important role in contributing to the learner's education [17] [18]. As it shown in Figure 4, the teacher is helping the students who are in need. It is called (ZPD).

\subsection{The Role of Needs}

The Montessori methodology of learning emphasizes the developmental needs of learners. One of the most outstanding objectives of Montessori teaching is to

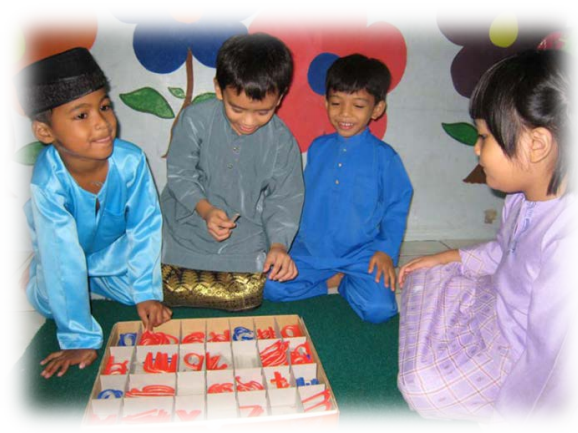

Figure 3. Doing by thinking.

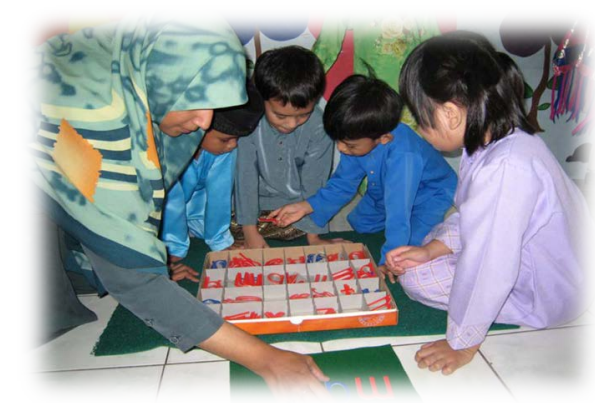

Figure 4. The role of instructor. 
foster competency and a sense of responsibility in the mind of young learners. In the Montessori classroom, everybody has a role to play. The teacher is committed to creating clear instructions to prepare pupils for the learning process in a specific environment. So, students do not need expert teachers to guide them all the way to achieve success. Role playing is thus an important pedagogical methodology of learning. [19]. The learner's prerequisite is engagement in a meaningful activity that enriches them physically and intellectually. Researchers agree that social-historical activity (play) theory can motivate learners to engage in the class and learn effectively [20]. Studies indicate that the success of the Montessori methodology is based on respect and individualistic attention given to the learners. Montessori instructors create an environment that is conducive for learning and let learners strive for excellence at their own pace. As thus creating environment that is conducive and encouraging [21]. The Montessori methodology emphasizes that learners should be given an opportunity to choose their own material for reading and learning. This personal autonomy helps them in the problem-solving process [22].

\section{Four Crucial Principles of the Montessori Method Self-Respect}

Develop self-respect for the learners.

Take the opportunity to educate yourself.

Respect teachers and adults.

Contribution with good intention.

Develop love for learning.

Be a responsible student.

Consider knowledge as a source of great pleasure.

Appreciate the fact that learners are born with unseen talents.

\subsection{Teaching}

Cognitive and sensory learning is important.

We should unlock the learner's mind.

Mental power is critical.

Early childhood education is crucial.

\subsection{Theory}

Learning is acquired through exploration.

The environment is the key to learning.

Sensory-based learning methods are preferred.

Stimulation of senses is the key to learning.

\subsection{Students}

They learn stylishly and innovatively.

Each learner is a unique being. 
Learners have freedom of choice.

Each learner learns differently.

Learners have attached values.

\section{Critics of Montessori Learning}

Although Maria Montessori devoted much of her life to educating children, her critics argue that her theory of learning has created many problems for learners. The Montessori approach has been criticized for giving too much freedom to young learners and leaving them in the classroom without proper supervision. As a result, children often fight among themselves rather than engage in learning tasks. Older learners naturally suppress the younger ones for supremacy and above all for the possession of their favorite toys. In a Montessori classroom, learners are often not friendly or rule abiding learners. They break every rule to be the winner in the class.

There is no creativity as well as interaction among the learners [23]. In fact, the effectiveness of the Montessori theory is not really proven and studies suggest that the measurement of sensory approach to learning outcome is unsatisfactory [24] [25]. From Dewey's point of view, the Montessori approach does not encourage creativity and the classroom is not adequately stimulating. Besides, Montessori's teaching materials are very expensive and highly specialized; most parents cannot afford to purchase them for their children to practise at home. Moreover, the Montessori concept of childevaluationhas been criticized for being poor and unsystematic. Progress is recorded in report cards, making it difficult to assess accurately the learners' success or failure [26]. Eye witnesses have expressed shock at the way learners are allowed to roam around in a Montessori compound: "Everything about it seems a little off. I mean, they got kids playing out on the playground at all times of the day. And scraping away on those weird Mexican gourds. What kind of school is that?" Kramarczyk asked. "And the teachers have always got the kids doing these weird little puppet shows. That's gotta tell you something right there". But however, the Montessori learning methodology is still relevant and its socially rich environment is mind blowing [27].

\section{Methodology}

In this research, qualitative, quantitative and observation methods of data collection were used. The qualitative method was used to collect and analyze data while the quantitative method was used to strengthen the qualitative data. The independent variable in this research was the Montessori method of instruction. The dependent variables were the learners' problem-solving skills, critical thinking skills, and students' behavioral changes. The instruments used to collect data were 1) pre-test and post-test, 2) field observation of learners' facial expression, satisfaction, and motivation in the classroom, 3) questionnaires, interviews, and participants' opinions. One day before the commencement of the experi- 
mentation, the researcher administered a pre-test to evaluate the pupils' proficiency in mathematics. A post-test was conducted after a lapse of four months during which the experimental group utilized the Montessori method of learning mathematics.

\section{Results}

180 students participated in this study. Based on the interviews, questionnaires and special pre- and post-tests, the majority of the pupils in the experimental group were of the view (interview) that the Montessori method helped them to improve their mathematical proficiency, critical thinking skills, problem solving skills and they were disciplined in the class.

\section{Control Group}

\section{PRE-TEST:}

Students were given a general test about counting, critical thinking and problem solving. The purpose of the test was to gauge their basic knowledge in mathematics. After the pre-test, they were taught in the traditional manner using a chapter of the kindergarten syllabus for four months without any intervention.

The following are the test scores in the pre-test:

Final scores combined for all three categories (mathematical assessment)

(critical thinking, problem solving, and discipline)

Pass Marks

\begin{tabular}{llll} 
Critical thinking: & 30 MARKS & $\mathrm{N}=20 / 90$ pass & (22.3\% pass) \\
Problem solving: & 30 MARKS & $\mathrm{N}=25 / 90$ pass & $(27.8 \%$ pass $)$ \\
Discipline: & 40 MARKS & $\mathrm{N}=35 / 90$ pass & $(38.9 \%$ pass $)$ \\
& \multicolumn{2}{c}{ Total: $29.6 \%$} & \\
& \multicolumn{2}{c}{ Fail Marks } \\
Critical thinking: & 30 MARKS & $\mathrm{N}=70 / 90$ fail & $(77.8 \%$ fail $)$ \\
Problem solving: & 30 MARKS & $\mathrm{N}=65 / 90$ fail & $(72.3 \%$ fail $)$ \\
Discipline: & 40 MARKS & $\mathrm{N}=55 / 90$ fail & $(61.2 \%$ fail $)$
\end{tabular}

Total: $72.4 \%$

\section{POST-TEST:}

After four months, students were given a post-test that assessed skills in critical thinking and problem solving. Their discipline in class was also noted. The following are the post-test scores: Final scores combined for all three Categories (mathematical assessment) (critical thinking, problem solving and discipline)

Pass Marks

$\begin{array}{llll}\text { Critical thinking: } & 30 \text { MARKS } & \mathrm{N}=55 / 90 \text { pass } & (61.2 \% \text { pass }) \\ \text { Problem solving: } & 30 \text { MARKS } & \mathrm{N}=60 / 90 \text { pass } & \text { (66.7\% pass) } \\ \text { Discipline: } & 40 \text { MARKS } & \mathrm{N}=65 / 90 \text { pass } & \text { (72.2\% pass) }\end{array}$

Total: $66.7 \%$ 
Fail Marks

$\begin{array}{llll}\text { Critical thinking: } & 30 \text { MARKS } & \mathrm{N}=35 / 90 \text { fail } & (38.9 \% \text { fail }) \\ \text { Problem solving: } & 30 \text { MARKS } & \mathrm{N}=30 / 90 \text { fail } & (33.4 \% \text { fail }) \\ \text { Discipline: } & 40 \text { MARKS } & \mathrm{N}=25 / 90 \text { fail } & (27.8 \% \text { fail })\end{array}$

Total: $33.4 \%$

\section{Experimental Group}

\section{PRE-TEST:}

Students were given the same test as that for the control group. Similarly, the purpose of the test was to assess their basic knowledge in mathematics. The following are the test scores in the pre-test: Final scores combined for all three Categories: (mathematical assessment) (critical thinking, problem solving and discipline)

Pass Marks

\begin{tabular}{|c|c|c|c|}
\hline Critical thinking: & 30 MARKS & $\mathrm{N}=35 / 90$ pass & (38.9\% pass) \\
\hline Problem solving: & 30 MARKS & $\mathrm{N}=35 / 90$ pass & (38.9\% pass) \\
\hline Discipline: & 40 MARKS & $\mathrm{N}=20 / 90$ pass & (22.3\% pass) \\
\hline \multicolumn{4}{|c|}{ Total: $33.6 \%$} \\
\hline \multicolumn{4}{|c|}{ Fail Marks } \\
\hline Critical thinking: & 30 MARKS & $\mathrm{N}=55 / 90$ fail & (61.2\% fail) \\
\hline Problem solving: & 30 MARKS & $\mathrm{N}=55 / 90$ fail & (61.2\% fail) \\
\hline Discipline: & 40 MARKS & $\mathrm{N}=65 / 90$ fail & (72.3.\% fail) \\
\hline
\end{tabular}

\section{POST-TEST:}

The participants in the control group were taught the same chapter of the kindergarten syllabus as that used by teachers in the control group. However, the teachers used the Montessori method for the control group for the same duration, i.e. four months. The following are the test scores in the post-test: Final scores combined for all three Categories: (mathematical assessment) (critical thinking, problem solving and discipline).

Pass Marks

\begin{tabular}{|c|c|c|c|}
\hline Critical thinking: & 30 MARKS & $\mathrm{N}=75 / 90$ pass & (83.4\% pass) \\
\hline Problem solving: & 30 MARKS & $\mathrm{N}=70 / 90$ pass & (77.8\% pass) \\
\hline Discipline: & 40 MARKS & $\mathrm{N}=70 / 90$ pass & (77.8\% pass) \\
\hline \multicolumn{4}{|c|}{ Total: $79.7 \%$} \\
\hline \multicolumn{4}{|c|}{ Fail Marks } \\
\hline Critical thinking: & 30 MARKS & $\mathrm{N}=15 / 90$ fail & (16.7\% fail) \\
\hline Problem solving: & 30 MARKS & $\mathrm{N}=20 / 90$ fail & (22.3\% fail) \\
\hline Discipline: & 40 MARKS & $\mathrm{N}=20 / 90$ fail & (22. 3\% fail) \\
\hline
\end{tabular}

As apparent from the scores of the Post-test for the experimental group, pu- 
pils who utilized the Montessori learning method (79.7\% pass/20.5\% fail) outperformed their peers who did not use the Montessori method of learning (66.7\% pass $/ 33.4 \%$ fail) in all the three categories (Table 1) (critical thinking, problem solving and discipline).

\section{Hypothesis Testing}

\subsection{Hypothesis One}

\section{Effect of Montessori Learning on Thinking Skills}

Instructors who use the Montessori approach view learners' minds as a locked playground that must be unlocked to achieve learning outcomes. The results of the pre-test and post-test in this study indicated that the Montessori method indeed helped students to be more alert and improved their critical thinking skills. Moreover, learners acquired the necessary skills to achieve academic excellence in mathematics. The improved scores on the thinking skills aspect of the test validated the hypothesis $\mathrm{H}^{1}$, that learners who utilized the Montessori method improved their thinking skills.

\subsection{Hypothesis Two}

\section{Effect of Montessori Learning on Problem-Solving Skills}

Based on the Montessori approach, education is not what the teacher gives but is a natural process spontaneously carried out by the individual, and learning is acquired not by listening to words but by experiences in carrying out specific tasks. In the Montessori environment, pupils are challenged with problems so that they can think for themselves. Once they are given the opportunity to think critically, new knowledge is created. The improved scores on the problem-solving skills aspect of the test validated the hypothesis $\mathrm{H}^{2}$, that learners who utilized the Montessori method increased their problem-solving skills.

\subsection{Hypothesis Three}

Effect of Montessori Learning on Learners' Sense of Responsibility and Discipline in the Class

One of the most outstanding objectives of the Montessori teaching is to foster competency and a sense of responsibility. In the Montessori classroom, everybody has a role to play. The teacher is committed to creating clear instructions and to prepare pupils for the learning environment. Pupils do not need expert

Table 1. Comparison between control and experimental groups.

\begin{tabular}{lrlr}
\hline \multicolumn{2}{c}{ Control Group: $\mathbf{N}=\mathbf{9 0}$} & \multicolumn{2}{c}{ Experimental Group: $\mathbf{N}=\mathbf{9 0}$} \\
\hline Pre-Test & Post-Test & Pre-Test & Post-test \\
\hline 29.6\% Pass & 66.7\% Pass & $33.6 \%$ Pass & $79.7 \%$ Pass \\
$72.4 \%$ Fail & $33.4 \%$ Fail & $64.9 \%$ Fail & $20.5 \%$ Fail \\
Significant (48.1\%) Over all pass marks & Significant (56.6\%) Over all pass marks \\
from the Traditional Teaching. & from the Montessori Teaching.
\end{tabular}


teachers to achieve successful learning. The improved scores on behavioral change component of the test validated hypothesis $\mathrm{H}^{3}$, that learners who utilized the Montessori method improved their behavior in the classroom.

\section{Discussion and Conclusion}

Regardless of very harsh criticism of the Montessori method of teaching and learning, Montessori kindergartens have continued to enjoy considerable popularity worldwide. The Montessori approach is simply that children learn in a unique way, distinct from the way adults learn. Instructors should not ignore the absorbent minds of these unique individuals. Much importance is placed on sensory learning as an effective and efficient means of educating children. Educators cannot ignore Montessori's spontaneity in the classroom. However, the Montessori concept of learning has not offered yet a harmonious learning condition for our learners. When young learners are left without adequate supervision for a long time, they might be exposed to the existing environmental danger. Hence, there is still room for improvement.

\section{Future Study}

This research explored the important role played by the Montessori approach to teaching and learning mathematics at kindergarten level. Similar investigations are needed using learners from different academic years to investigate the beneficial effects of the Montessori method in the classroom. More rigorous studies are needed to investigate other effects of the Montessori method on primary school children to find out how sensory-based teaching method can help improve critical thinking skills, problem solving skills and inculcate responsible behavior in the classroom. Figure 5 and Figure 6 below show the educational instruments used to teach young children.

\section{Limitations of the Study}

This research investigated the effectiveness of the Montessori method of instruction at kindergarten level. Hence, the findings cannot be generalized to other age groups. More in-depth studies should be conducted to examine how the

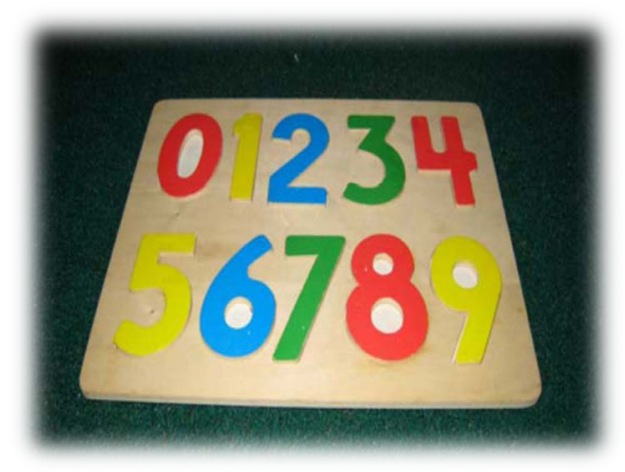

Figure 5. Montessori instruments. 


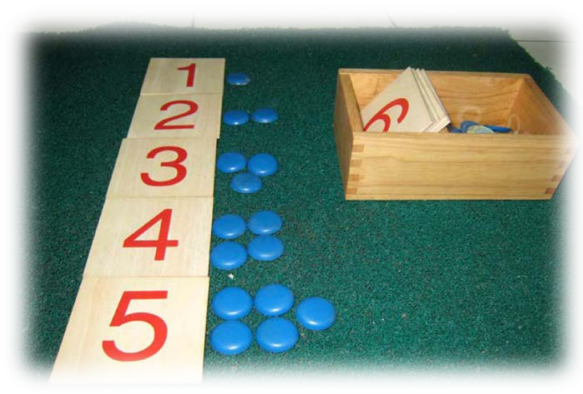

Figure 6. Montessori instruments.

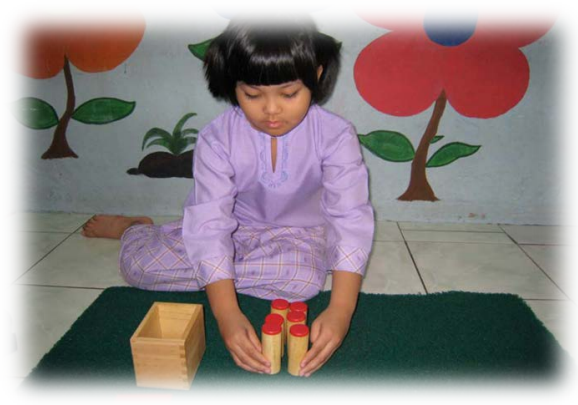

Figure 7. Thinking skill.

Montessori method of teaching can be exploited for learning not only mathematics, but also other subjects such as science. This experimentation was carried out only for a period of four months with a total of 180 participants. A longer study period with a larger sample would yield more conclusive results. Figure 7 indicates the importance of thinking in learning mathematics and problem solving in the class.

\section{Acknowledgements}

Many thanks and appreciations to the kindergarten (TadikaBestari Al-Hidayah), located in Bandar Seri Damansara, Malaysia for creating the experimental environment.

\section{References}

[1] Torelli, J.N., Lloyd, B.P., Diekman, C.A. and Wehby, J.H. (2017) Teaching Stimulus Control via Class-Wide Multiple Schedules of Reinforcement in Public Elementary School Classrooms. Journal of Positive Behavior Interventions, 19, 14-25. https://doi.org/10.1177/1098300716632878

[2] McKenzie, G.K. and Zascavage, V.S. (2012) Montessori Instruction: A Model for Inclusion in Early Childhood Classrooms and beyond, Montessori Life: A Publication of the American Montessori Society, 24, 32-38.

[3] Huxel, A.C. (2013) Authentic Montessori: The Teacher Makes the Difference. Montessori Life: A Publication of the American Montessori Society, 25, 32-34.

[4] Lillard, A.S. (2013) Playful Learning and Montessori Education. American Journal of Play, 5, 157-186.

[5] Taylor, L.H. (2017) Supporting Elementary Children in Crisis. NAMTA Journal, 42, 
193-247.

[6] Faryadi, Q. and Zainab, H. (2008) Determining a Theoretical and an Empirical Based Interactive Multimedia Arabic Language Courseware to Teach Arabic as a Foreign Language. Proceedings of Knowledge Management International Conference, Langkawi, 75-80.

[7] Bahmaee, A.B., Saadatmand, Z. and Yarmohammadian, M.H. (2016) Principle Elements of Curriculum in the Preschool Pattern of Montessori. International Education Studies, 9, 148-153. https://doi.org/10.5539/ies.v9n1p148

[8] Rajan, R.S. (2017) Music Education in Montessori: An Exploratory Study of School Directors' Perceptions in the United States. International Journal of Music Education, 35, 227-238. https://doi.org/10.1177/0255761416659508

[9] Kumar, S.P. and Nathan, B.S. (2016) Development of Multisensory Integration Approach Model. International Journal of Applied Research, 2, 629-633.

[10] Özdemir, M. and Kaptan, F. (2017) Analyzing the Learning Styles of Pre-Service Primary School Teachers. Journal of Education and Practice, 8, 11-19.

[11] Miller, L.J. and Kinnealey, M. (1993) Researching the Effectiveness of Sensory Integration. Sensory Integration Quarterly, XXI, 2-7.

[12] Moll, I. (2004) Towards a Constructivist Montessori Education. Perspective in Education, 22, 37-50.

[13] Bower, B. (2006) Montessori Learning Aid: Alternative School Shows Impact on Poor Children. Science News, 170, 212-213. https://doi.org/10.2307/4017446

[14] Alonazi, S.M. (2017) The Role of Teachers in Promoting Learner Autonomy in Secondary Schools in Saudi Arabia. English Language Teaching, 10, 183-202. https://doi.org/10.5539/elt.v10n7p183

[15] Jacobs, G.M. and Chin, W.K. (2017) Cooperative Learning with One Student? Yes. IASCE Journal, 36, 11-13.

[16] Smith, D.R. (2005) The Egg Man and The Empress. Montessori Life: A Publication of the American Montessori Society, 17, 50-54.

[17] Rathundi, K. and Csikszentmihalyi, M. (2005) Middle School Student's Motivation and Quality of Experience: A Comparison of Montessori and Traditional School Environments. American Journal of Education, 111, 341.

[18] Miretzky, D. (2017) Teaching the Class with "The Class": Debunking the Need for Heroes. Multicultural Education, 24, 40-48.

[19] Belova, N., Eilks, I. and Feierabend, T. (2015) The Evaluation of Role-Playing in the Context of Teaching Climate Change. International Journal of Science and Mathematics Education, 13, 165-190.

[20] Broström, S. (2017) A Dynamic Learning Concept in Early Years' Education: A Possible Way to Prevent Schoolification. International Journal of Early Years Education, 25, 3-15.

[21] Chipangura, A. and Aldridge, J. (2017) Impact of Multimedia on Students' Perceptions of the Learning Environment in Mathematics Classrooms. Learning Environments Research, 20, 121-138.

[22] Lillard, A.S. (2013) Playful Learning and Montessori Education. NAMTA Journal, 38, 137-174. (Reprinted)

[23] Humphries, T., Wright, M., McDougall, B. and Verites, J. (1990) The Efficacy of Sensory Integration Therapy for Children with Learning Disability. Physical and Occupational Therapy in Pediatrics, 10, 1-17. 
[24] Kratzig, G., Arbuthnott, P. and Katherine, D. (2006) Perceptual Learning Style and Learning Proficiency: A Test of the Hypothesis. Journal of Education Psychology, 98, 238-248.

[25] Wu, T.-J. and Tai, Y.-N. (2016) Effects of Multimedia Information Technology Integrated Multi-Sensory Instruction on Students' Learning Motivation and Outcome. EURASIA Journal of Mathematics, Science \& Technology Education, 12, 1065-1074.

[26] Dewey, J. (1897) My Pedagogic Creed. The School Journal, LIV, 77-80.

[27] Andrews, S.W. (2015) The Social Relevance of Montessori in the First Plane. NAMTA Journal, 40, 31-61.

Submit or recommend next manuscript to OALib Journal and we will provide best service for you:

- Publication frequency: Monthly

- 9 subject areas of science, technology and medicine

- Fair and rigorous peer-review system

- Fast publication process

- Article promotion in various social networking sites (LinkedIn, Facebook, Twitter, etc.)

- Maximum dissemination of your research work

Submit Your Paper Online: Click Here to Submit

Or Contact service@oalib.com 